\title{
Digital marketing: A conceptual framework
}

\author{
A. Gaur ${ }^{1}$ and Sweta ${ }^{2 *}$ \\ ${ }^{1 \& 2}$ Department of Business Administration, Chaudhary Devi Lal University, Haryana, India
}

DOI: http://doi.org/10.52814/PJMA.2021.1104

ARTICLE TYPE: Review paper

ARTICLE HISTORY: Submitted: January 2021, Revisions: March 2021, Accepted: March 2021

HOW TO CITE: Gaur, A. and Sweta (2021). Digital marketing: A conceptual framework. Prayukti - Journal of Management Applications, Vol. 1, Issue 1, pp. 2933.

*Corresponding author e-mail: shwetaonline121@gmail.com

\begin{abstract}
Digital marketing is an expansive term that incorporates all showcasing channels and techniques you can use to advance items or administrations on the Internet yet in addition on electronic gadgets, for example, TVs, cell phones and electronic bulletins. The principle contrast between digital marketing and customary promoting is that computerized showcasing efforts are executed solely through advanced channels and this gives advertisers more control, devices, and information to dissect the adequacy of a battle. This paper includes the conceptual framework of the digital marketing such as introduction, meaning, constituents, impact of digital marketing and business models. The paper helps to know about the various methods for the digitalization of the business and different models which should be adopted by the business.
\end{abstract}

KEYWORDS: Digital Marketing, Business, Digitalization, Models.

\section{INTRODUCTION}

To maintain the business refreshed with the 21 st century's marketing strategies. To stay aware of the ever-developing rivalry, private ventures need to make their organizations Digital. There is a reliable and clear development in the Digital Marketing industry and this is the ideal opportunity to make your digital nearness felt. Organizations influence digital channels, for example, web indexes, internet based life, email and their sites to interface with current and forthcoming clients. In basic terms, any type of marketing that exists online is called Digital Marketing.

The digital innovation has radically changed the manner in which organizations work today. Presently, advertisement organizations approach their promotion battles in an amazingly unique manner. Huge organizations and brands are not just the ones who profit by internet marketing. Truth be told, the independent companies can likewise profit tremendously from digital marketing. Henceforth, organizations today are using the digital universe to make brand mindfulness, effect and drive clients. Digital marketing is 
characterized as a marketing approach that essentially depends on the web to associate with the intended interest group through different digital media channels and stages.

\section{MEANING OF DIGITAL MARKETING}

Digital marketing alludes to all types of marketing which utilize an electronic gadget associated with the web. Brands and organizations gain by the digital channels, for example, web based life, web search tools, outsider sites, email and so forth to interface and connect with their ebb and flow and imminent clients and create leads. The kind of marketing utilizes different digital procedures by organizations to interface with their clients. In basic words, digital marketing will be marketing that is done on the web. Digital marketing is a comprehensive term that comprises of digital channels, for example, content marketing, SEO, email marketing, web based life marketing, versatile marketing, etc, to make expound procedures to reach and associate with possibilities and clients. A normal client devours content through the TV, PC, tablet, cell phone, radio, and other customary media. This consistent introduction to different sorts of media has prompted data over-burden, further confounding the purchaser's excursion. Digital marketing has permitted brands to remain pertinent by making themselves noticeable through various channels and touch points.

\section{CONSTITUENTS OF DIGITAL MARKETING}

There are some constituents which should be following under digital marketing.

\subsection{Search Engine Optimization (SEO)-}

In the least difficult of terms, SEO is the way toward making your site noticeable on online search engines like Google, Bing, and so on. The activity of a SEO proficient is to enhance a business' site in such a way, that it positions higher in the search results and not remain covered up in obscurity corners of the second page of Google. This expands the measure of natural traffic on the site. Web optimization significantly uses the intensity of sites, websites, recordings, and info graphics. There are different methods of drawing closer SEO so as to create qualified site traffic.

\subsection{Pay per Click (PPC)-}

PPC is a strategy of coordinating traffic towards the site by the methods for paid advertisements on web indexes. As the name recommends, the brands need to pay the promotion distributer each time somebody clicks on the advertisement. One of the most wellknown stages for PPC battles is Google Ads, which permits brands to pay (per click) for top openings on the indexed lists page of Google. There are different channels to run PPC battles, some of which are Facebook, Twitter, supported messages on LinkedIn, and so forth.

\subsection{Content Marketing-}

Content marketing manages the creation and advancement of significant substance as blog entries, recordings, info graphics, bullet point articles, and so forth to draw in with the current and planned clients, improving brand faithfulness, producing brand mindfulness, site traffic development, and lead age. A powerful substance technique incorporates channels, for example.

\subsection{Blog Entries-}

Writing and distributing enlightening online journals and articles on the organization blog sets up your expertise and authority in the business and aides in producing natural traffic for the site. This empowers you to change over the site guests into leads for your business group.

\subsection{Video Content-}

In the 21 st century, video content has begun to quickly supplant the composed type of substance. Partner the brand with creative short stories by means of the visual medium is probably the most ideal approaches to improve brand review. 


\subsection{Social Media Marketing-}

Hardly anybody on the planet is left immaculate by the appeal of Social Media. At the point when a brand's intended interest group is investing most of their energy looking on Facebook or Instagram, it will be imprudence on the brand's part to not be available on their faithful clients' preferred web based life stages. Online networking marketing fundamentally manages advancing the brand and substance via web-based networking media channels to make mindfulness, draw in with current and imminent clients, drive traffic, and produce leads for the business. The significant online life channels where a brand's essence is an unquestionable requirement are Facebook, Twitter, Instagram, LinkedIn, Snapchat, and Pinterest.

\subsection{Email Marketing-}

Email marketing, whenever utilized effectively, is a very productive route for the brands to speak with their crowd. Email crusades are fundamentally utilized for advancing substance, occasions, limits, and so forth and are a successful method of coordinating beneficiaries towards the brand's site. The email battles may incorporate substance, for example, blog memberships, bulletins, subsequent meet-ups on the leads, occasion advancements and so forth

\subsection{Affiliate Marketing-}

Affiliate marketing is the way toward gaining a commission by advancing others' (or company's) items. You discover an item you like, elevate it to other people, and procure a bit of the benefit for every deal that you make.

\section{IMPACT OF DIGITAL MARKETING ON BUSINESS}

\subsection{Increment in brand recognition-}

Today, the greater part of the world's people utilizes online life stages. It makes internet based life the characteristic spot to interface with exceptionally focused on expected purchasers. This can expand the brand mindfulness that your image merits.

\subsection{Generation of leads-}

Digital media is a low-responsibility path for new clients to show an enthusiasm for a business and its items. Getting leads is a significant bit of leeway internet based life brings to any business. They are an indication that clients are keen on the brand and its items.

\subsection{Support in deals -}

An extraordinary digital marketing methodology can acquire great business and open doors for a brand. The quantity of individuals who utilize online life is on the ascent and social deals devices keep on advancing. This will make online networking systems progressively significant for web based business and item search.

\subsection{Involvement of customers and audience-}

Online networking stages are an open door for brands to straightforwardly interface with clients and the other way around. Customary media was a single direction road when it came to correspondence; online networking takes into consideration a discourse between the brand and its crowd.

\subsection{Customer communication-}

Digital stages and web based life has empowered simple and moment correspondence between the brand and the crowd. What's more, the best thing is, it assists with interfacing with the worldwide crowd.

\subsection{Content distribution -}


Consistently, a business can impart colossal substance to the crowd through internet based life, messages, applications, bulletins, etc. Along these lines advertisers can without much of a stretch spread their message to an enormous crowd.

\subsection{Customer information-}

With the assistance of innovation, organizations can follow the information of the clients. The examination of the information can assist your business with getting to realize client's preferences and inclinations. In view of this, you can settle on fundamental business choices. State, you need to present another item and afterward you allude to client data.

\subsection{Encourage information-}

Digital marketing offers a stage to arrive at clients in an imaginative manner. When there is a hardened rivalry in the market, having a creative methodology encourages brands to stick out.

\section{STEPS FOR IMPLEMENTING DIGITAL BUSINESS MODELS}

\subsection{Problem-}

The initial step subsequent to specifying a plan of action thought is the supposed Problem/Solution-Fit. This is the place the accepted issues and needs of the client are approved. In this stage, the organization must concentrate on subjective viewpoints to take in however much as could reasonably be expected from the client and build up an appropriate arrangement.

\subsection{Product-}

When the fit between client issues and arrangement is approved, the Product/MarketFit stage checks whether clients are keen on the plan of action in general, including the blend of administrations, items and its highlights. The primary goal is to distinguish the "absolute necessities" and the general attractive quality of the arrangement.

\subsection{Voluntaries to pay-}

This third step is about profound plunging into the income model. Numerous organizations think that it's hard to not check the readiness of clients to pay until this progression, as this is the urgent angle from their perspective. At last, in any case, the immediate enthusiasm of the client, which is checked in the past stages, is the most solid sign to this point a gainful plan of action can be created.

\subsection{Value delivery phase -}

When the eagerness to pay has been approved and pilot clients have been distinguished, the Value Delivery Phase can be utilized to plan and build up the creation and coordination's forms required, which collaboration accomplices are fundamental and how the specific cost structure will resemble.

\subsection{Scaling-}

In the last advance preceding the (pilot) showcase section, it is important to decide how the accomplishment of the plan of action really looks like and how this can be estimated. Here, run of the mill development and monetary key figures might be sufficient, yet because of the vital character of new plans of action, angles, for example, collaboration impacts and scaling potential are additionally significant variables.

\section{CONCLUSION}

The study concludes that digital marketing leads a great effect on the business and helps a vital role in the development of economy as well as the business progression. With digital marketing private ventures can pull in an enormous number of crowds. Computerized advertising is a practical method to change your business. Subsequently, it is insightful for the independent company to use the capability of computerized advertising and excel in their 
business. By using the different digital methods any business can expand in foreign country and generate high revenue. So the conclusion of the study is that digitalization of business is significant to improve the expansion as well as wealth of the organization.

\section{REFERENCES}

- Media, S. R. V. (n.d.). Digital Marketing Company in India. Retrieved July 5, 2021, from Srvmedia.com website: https://www.srvmedia.com/.

- Neil Patel: Helping you succeed through online marketing! (2015, November 18). Retrieved July 5, 2021, from Neilpatel.com website: https://neilpatel.com/.

- SEO and Digital Marketing Services since 2002 - reliablesoft.Net. (2018), September 17). Retrieved July 5, 2021, from Reliablesoft.net website: https://www.reliablesoft.net/.

- Walke, S. G.; Shetiya, Mahavir M. and Kumar, Atul (2019). A Study of Sustainable Business Practices for Online Business. International Journal of All Research Education and Scientific Methods. Vol. 7, Issue 3, pp. 51-58.

- Kumar, Atul and Brar, Vinaydeep (2018). Digital Marketing and Role of Blockchain in Digital Marketing Industry. International Journal of All Research Education and Scientific Methods. Vol. 6, Issue 12, pp. 23-26.

- Live \& Interactive Learning - Talentedge. (2016, July 19). Retrieved July 5, 2021, from Talentedge.com website: https://talentedge.com/.

- \#1 digital marketing agency Denver. (2018, December 18). Retrieved July 5, 2021, from Maxeffectmarketing.com website: https://www.maxeffectmarketing.com/.

- No title. (n.d.). Retrieved July 5, 2021, from Toolbox.com website: https://marketing.toolbox.com/.

- (N.d.). Retrieved July 5, 2021, from Bmilab.com website: https://bmilab.com/blog/2020/3/19. 